УДК

Оригиналан научни рад

Примљен: 16. 5. 2016.

Прихваћен: 16.1.2017.

Srđan CVETKOVIĆ

Institute for Contemporary History

scevtkovic72@gmail.com

\title{
Fall of Aleksandar Ranković and Condemnation of "Rankovićism"*
}

\begin{abstract}
This study examines the circumstances which lead to the purge of Aleksandar Ranković, the longtime person "Number one" in the State Security's apparatus. The study also analyses the impact it had on the future events in the history of Yugoslavia. The political fall of Aleksandar Ranković coincided with the beginning of the process of redefining relations between the member-states of the Federation sparkling suspicions that the two events were closely interlinked. Moreover, Aleksandar Ranković was posthumously proclaimed Serbian nationalist. In this study, we also analyse what affairs during the Rankovićs ouster can be linked to his name; how much truth there is in the accusations of his involvement in the wire-tapping of the Yugoslav top level political leaders' affair and what were his ambitions to become one of them. What implications did these events have on the wider scope of the state's political actions?
\end{abstract}

Key words: Aleksandar Ranković, UDBA (State Security Administration), communism, Serbia, political purges, party purges, Josip Broz Tito

According to the common view of historians, Aleksandar Ranković's fall from power was the result of his opposed efforts to the pro-

This article has been written within the framework of the scholarly project: Serbian Society in the Yugoslav State in the $20^{\text {th }}$ century: Between Democracy and Dictatorship (№ 177016), financed by the Ministry of Education, Science and Technological Development of the Republic of Serbia. 
motion of decentralization and constitutional reforms after $1963 .{ }^{1}$ The mainstream interpretations of Edvard Kardelj's concept of the national question emphasise that during the fall of Aleksandar Ranković Yugoslavia was in the process of gradual redefinition to a federation of independent states (republics) invoking the right to self-determination and secession. During the $8^{\text {th }}$ Congress of the League of Communists of Yugoslavia in 1964, it was decided that republics' congresses were to be held before the Congress of the League of Communists of Yugoslavia therewithal nationality balance was maintained (parity of national representation) within the state and party institutions became major concern. Soon after the fall of Ranković, the acceptance of an amendment giving favourable status to the Serbian provinces (Vojvodina and Kosovo) led to further strengthening of nationalism within the Party. The fall of Ranković did not provoke radical changes and purges within the Party as much as did the fall of the "liberals" during the 70s (apart from those within the state security in Serbia and Kosovo). However, consequences of the Brioni Plenum have deeply affected the course of the socio-political life, the system and, after all, the fate of the state. Is there any truth in the accusations against Ranković? Under what circumstances was the first man of the state security dismissed and what did this really mean for the history of Yugoslavia?

\section{Security's Number One - Party's Number Two}

Political and war biography of the Security's First man and the Second to Tito is exciting and dynamic. His inexhaustible work energy, brilliant organisational skills, experience of an old revolutionary and his unscrupulousness raised him to the highest political ranks. As a member of the HQ of the National Liberation Army (NOV), and Partisan Armed Forces (POJ) and Secretary-General of the Communists Party of Yugoslavia (KPJ) during the war, he was also member of the Tito's inner circle. He was involved in the most important decisions concerning war and revolution affairs. He was a member of the most important army and political organisations of the Yugoslav liberation movement: member of the Anti-Fascist Council of National Liberation of Yugoslavia, (AVNOJ),

1 It was commonly noted that serious disagreements begun as early as in 1958 and lasted through to 1962 followed by more intensive ones including activities preceding Ranković's dismissal. Milan Piljak, „Brionski plenum 1966. godine: pokušaj istoriografskog tumačenja događaja“, Tokovi istorije 1/2010, 76-77. 
vice-president of the Anti-Fascist Assembly of National Liberation of Yugoslavia, (ASNOS) delegate of the Temporary and Constituent Assembly of Democratic Federation of Yugoslavia (SDFJ). When, the first state security agency, the Department of People's Security (OZNA) was formed on May $13^{\text {th }}, 1944$ on the island Vis (Croatia), Aleksandar Ranković became its first chief. Following the adoption of the Yugoslav Constitution in spring 1946, he was named Interior Minister of the Federal National Republic of Yugoslavia (FNRJ). Later, he was appointed to the highest state and party positions including Vice-President of the Federal Government and become a national delegate. He was twice re-elected member of the Politburo and a member of the Executive Committee of the Central Committee of the Communist Association of Yugoslavia (CK SKJ) at the Fifth (1948) and Sixth (1952) Party congresses. In 1956, he became Vice-President of the Federal Executive Council (SIV) and President of the Committee for Internal Politics and Security, member of the Secretariat of the Executive Committee of the Central Committee of the League of Communists of Yugoslavia (CK SKJ), member of the Central Committee of the League of Communists of Serbia (CK SKS), and a member of the Presidium of the Federal Committee of the League of the Socialist Working People of Yugoslavia (SSRNJ). After the war and until 1966, he was official and also unofficial chief of all civil secret services. ${ }^{2}$

2 Aleksandar Ranković was born on November $28^{\text {th }}, 1909$ in a poor family in Draževac (Obrenovac) near Belgrade (Serbia). He lost his father at an early age. He completed elementary school in his native town and went to Belgrade to study to become textile worker (abadžija) and became an apprentice. He was very young when he joined the ranks of the Communist Youth League. Upon joining the Communist Party of Yugoslavia in 1928, he became a secretary of the Provincial Committee of the Communist Youth League of Serbia. Soon, he was caught in illegal distribution of communist propaganda material and was sentenced to 6 years in prison by the Court for the Protection of the Country. He served his sentence in the Sremska Mitrovica and Lepoglava prisons. In 1936 he became a member of the Provincial Committee of the Communist Party of Yugoslavia for Serbia, and in 1937 became a member of the Politburo of the Central Committee of the Communist Party of Yugoslavia. At the Fifth National Conference of the Communist Party of Yugoslavia in Zagreb he was elected to the Politburo of the Communist Party of Yugoslavia. After the uprising in late July 1941, at a time when Belgrade Radio station was sabotaged, he fell into the hands of the police. After the arrest, Ranković was taken to the Gestapo where he was tortured. His escape from the hospital was organized by S. C. Babović and $Đ$. Strugar supported by the undercover partisans in Belgrade. Ko je ko u Jugoslaviji, (Beograd: Sedma sila, 1957), 597-598. 
As an industrious operative, loyal to Tito, ${ }^{3}$ he significantly contributed to the strengthening and development of the state repression apparatus which successfully and efficiently eliminated remaining of the political opposition (Chetnicks, Ustasha, Rupniks) and later intra-party opposition - the Stalinists, the kulaks and the remaining "reactionists". His visit to the Goli Otok Island in 1951 and his speech at the Fourth Party Plenum meant radical change and indicated liberal policies toward political opposition. Ranković and his right hand Svetislav Stefanović-Ćeća were no longer in charge of the State Security Administration (UDBA) and the Federal Secretariat for Internal Affairs (SSUP) at the time of their ousting. However, Ranković was Vice-President of the Socialist Federal Republic of Yugoslavia (SFRJ) while Stefanović (Secretary of the Secretariat for Internal Affairs from 1953 to 1963) was a member of the Federal Executive Council (SIV) and President of the Committee for Internal Policy. In early 1965, the "third Ranković man" who was also removed from his position was Vojin Lukić, Secretary of the Federal Secretariat for Internal Affairs (SSUP). Accusations of misuse of the Secret Police (SDB) referred to times when Stefanović and Ranković were top-level federal security and internal affairs officers who used their political influence through their close allies Vojin Lukić in the Federal Secretariat for Internal Affairs and Srba Savić in the Secretariat of Internal Affairs (SUP). ${ }^{4}$

\section{Preparing to square accounts with the "Rankovicism"}

Tito's bold address against particularism, nationalism, republican economic localisms in Split, only few years before his 1962 clash with Ranković, was viewed as an attack against federalists and Kardelj's leaning toward Ranković ideology. The same year, at the plenum of Central Committee of the League of Communists of Yugoslavia (CK SKJ) such ideas were openly criticized and Kardelj was nearly sent home to Slovenia to continue with his scholarly work. ${ }^{5}$ However, by the beginning of Feb-

3 A. Ranković was Tito's best man at Tito and Jovanka's wedding in 1952. General Ivan Gošnjak was Jovanka's best man - author's note.

4 Archives of Yugoslavia, (Arhiv Jugoslavije-AJ), Supreme Court of Yugoslavia (Vrhovni sud Jugoslavije - VSJ), 212, f. 18, Izveštaj o deformacijama u radu Službe državne bezbednosti, Neposredno uplitanje Rankovića i Stefanovića u tekuće poslove SDB, 23.

5 This raised many suspicions about his hunting accident and the retreat to London. He only returned from London after an intervention by Bakarić, which was more of a political payoff. Kardelj was wounded by a bullet which went through his mouth stopping at a core of his spine. More on this incident in: Antun Duhaček, Ispovest 
ruary 1966 at the Third Party Plenum, Tito clearly had Ranković in mind when he criticized "individuals who fall under the influence of the petit bourgeois from the West and those reactionaries within the state who remained after the war." ${ }^{\prime 6}$ Those who supported Ranković were those who opposed market economy reforms and who believed that these reforms caused higher degree of techno-economic and political dependencies from capitalist countries and decentralisation thus giving the republics more independence. As many contemporaries recall, the relations between Tito and Ranković begun to deteriorate in the early 60s due to personal reasons. Tito allegedly kept passive during an argument between Jovanka Broz and Lazar Koliševski in 1961 and over the dismissal of General Milan Žezelj in 1964. ${ }^{7}$ Even later the death of Slobodan Penezić alias Krcun in a car accident on the Ibarska magistrala ${ }^{8}$ on November $5^{\text {th }}$, 1964 was under the scrutiny and interpreted in the context of preparing a showdown with Ranković. Tito also reacted in the same vein during the replacement of Vojin Lukić with the Croat Milan Mišković, whose brother Ivan was head of the military security service. The conflict intensified after Ranković's criticism of the constitutional reform at a rally in Trebišnica in February 1966 when he claimed that the developed republics were favoured. On the other hand, Tito and Bakarić indirectly criticized Ranković accusing him of conservatism and centralism. ${ }^{9}$ Since the mid60s, Ranković drew attention to himself as he increasingly toured Serbia where he was greeted with cheers, banners and music, which, some be-

obaveštajca, (Beograd,1992), 196; Biografija Josipa Broza Tita nepoznatog autora iz zaostavštine Milana Đokovića Popa - unpublished, author's possession.

6 Zdenko Radelić, Hrvatska u Jugoslaviji 1945-1990, (Zagreb: Globus, 2006), 360.

7 Vojin Lukić, Sećanja i saznaja, (Beograd: 1989), 123.

8 The basis for this speculation lies in Krcun's fiery nature and resilience to Tito's authority. There are recordings, that in moments of anger and despair Krcun allegedly would shout: "Man, we did not, fight for the ragged-Marx, but for Serbia!" Later, after the dismissal of the disobedient generals Radivoje Jovanović Bradonja (bearded), he, in the presence of Ranković, asked: "Comrade Tito, when is our turn?" These doubts were impassioned a quarter of a century later by the statement of Slavko Ristić, Head of the Department of Traffic Police, who claimed that he was forced to sign a false report. Milan Trešnjić, Podaci za biografiju Josipa Broza Tita, unpublished and in possession of the author.

10 Veljko Kirbus, „Moskovska zdravica za Rankovića, Prisluškivači“, feljton, Revija 92, No. 684, 2. 6. 2009; Miko Tripalo, Hrvatsko proljeće, (Zagreb: Globus, 1990), 81; Jože Pirjevec, Jugoslavija 1918-1992, (Kopar, 1995), 254, 257; Džasper Ridli, Tito, biografija, (Beograd: Mir, 1998), 413; Richard and Ben Chrampton, Eastern Europe in The Twentieth century, (London, 1997), 310. 
lieve, could have caught attention of his enemies in the party. ${ }^{10}$ According to the later SDB findings, intelligence services of the socialist countries allegedly counted on the "anti-reformists" around Ranković. However, the naive forecasts of the US intelligence suggested that it may result in a similar rebellion as in Hungary in April 1956. ${ }^{11}$

Even before the fall of Ranković and later during the Ranković inquiry, General Miloje Milojević, Commander of the $1^{\text {st }}$ Yugoslav Army stationed in Belgrade, was considered "nationalist and unitarian". The fact that Gen. Milojević and Gen. Radoje Jovanović "Bradonja" (ret. in 1958, expelled from KPJ in 1967) were paying frequent visits to Ranković and were also Vojin Lukić's war comrades did not go in their favour and caused some speculation. By the end of 1965, Gen. Milojević wrote a critically intoned report on personnel policy in the Yugoslav National Army (JNA). He intended to personally deliver the document to Ranković who was the organizing Secretary of the Central Committee (CK); however, Ranković refused it. In his report, Milojević criticized the position of Croats in the Army; especially those who were under the command of commandeer Ivan Gošnjak, who was also Minister of State for National Defence. He also argued that army officers from Montenegro were neglected and so on. Milojević filed his report to the military authorities who responded to it with violent campaign against him as a nationalist activist and against "all those in Serbia who support Milojević". General Milojević was excluded from the Party, dismissed from the Army and sent to early retirement. Lukić believes that the affair against Milojević may have been used against him for his alleged attempts to affect the Army's personnel policy which was heard in the accusations against Ranković. ${ }^{12}$

In early June 1966, the Federal State Security Administration (UDBA) already knew of Vladimir Bakarić's, Secretary of the Central Committee (SK) of Croatia, contact with a foreign ambassador in Belgrade at the end of May1966, according to Vojin Lukić. During this meeting he allegedly said that it should not come as a surprise if it was soon announced that Ranković was removed from the political life since it was a necessary move for democratization of the country. One of the first steps

10 Kirbus, „Moskovska zdravica za Rankovića”.

11 AJ, VSJ, 212, f. 18, top secret, 1966, Neka zapažanja o radu stranih obaveštajnih službi prema SFRJ u 1965. i 1966, 4; Momčilo Pavlović, Dokumenta CIA o Jugoslaviji 19481983, (Beograd: Institut za savremenu istoriju, 2008), 219-226.

12 Lukić, Sećanja i saznanja, 126; Svetko Kovač, Bojan Dimitrijević, Irena Popović, Slučaj Ranković - iz arhive KOS- $a$, (Zagreb: Despot Infinitus, 2016), 73-76. 
in the champagne against Ranković, Lukić believes, was removing Ranković from the office of the Federal Secretary of the Interior, an important role in the security system (executed in early 1965). The request for Ranković's shift to the position of Organizing Secretary was made by the Central Committee of the League of Communist of Serbia (CK SKS). There were no serious objections to his work. ${ }^{13}$ Lukić also notes that much bigger misuse of the Service was during 1944-1945 (liquidation of opposition without trial), followed by purges of Stalinist during 1948-1953 (especially Goli otok), and at the time of the "forced buyout campaign" against the farmers. This was common knowledge among the Party leaders; however, no one was punished because actions were taken strictly following Party and political directives. Lukić also believes that behind these campaigns were a majority of the Party leaders and Tito himself who all had desire to ouster Ranković but with no real intent to limit political abuse of Service and democratize society. ${ }^{14}$

\section{The wiretapping affair}

One of the main arguments in the case against Ranković and Stefanović was the unauthorized use of the technical resources for phone tapping within the UDBA to establish UDBA within itself and having later full control of UDBA from their new posts. The Service, allegedly, used UDBA for wiretapping and control of Party and state officials. ${ }^{15}$ Krste Crvenkovski was appointed President of the Commission organized to substantiate charges now made against Ranković regarding the misuse of the Service. Crvenkovski was Macedonian nationalist and this status made him better suited for political liquidation of Ranković than a Croat or a Slovenian. ${ }^{16}$ It has long been a mystery who participated in obtaining evidence against Ranković. Vojin Lukić claims that the Federal Security

13 Lukić, op. cit., 25.

14 Lukić observes that, not coincidentally, at the time of preparation confrontation with Ranković, he was sent to Mongolia and he only learned of the ousting of Ranković at the airport in a letter from Srba Savić which his son secretly gave him at the arrival in Belgrade: "I went to the toilet at the airport and then read the letter which Srba wrote on behalf of Ćaća, in which he informed me to be prepared for an attack on Ranković and the UDBA; and that all the accusations were false and fabricated aiming to discredit and politically liquidate Ranković and compromise and break UDBA staff; and that I should oppose it at the Plenum." Lukić, op. cit., 62-64, 71.

15 AJ, VSJ, 212, f. 18, Izveštaj o deformacijama u radu Službe državne bezbednosti, 6.

16 The same principles were most probably used to bring a "neutral" Macedonian Borče Samonikov, from Titov Veles as the Head of SDB. 
Service, as announced to the Commission Chairman K. Crvenkovski, was unable to detect listening devices in the Užička Street (Tito's residence) because it had no access to the premises. However, for some years the Military Security Service were in charge of the security there. Another peculiarity about the existence of the tapping devices was that the person who could have known was Selim Numić, head of the technical department but he persistently denied any knowledge. Stevo Krajačić, the longtime Head of the Security Services in Croatia, in an interview to the daily Vjesnik dated October $28^{\text {th }}, 1984$ boasted that the "Ranković conspiracy" and the mechanism of wiretapping were revealed through people and experts who were illegally sent from the Croatian Secretariat for Internal Affairs. ${ }^{17}$ It seems rather odd that Tito, as the cables were allegedly discovered, did not suspect a foreign intelligence plot. However, he immediately pointed his finger at his security service, Ranković and Stefanović, his longtime close associates.

The pressure of many top Party leaders at the Brioni Party Plenum to ouster Ranković was overt and intense. Despite his undisputed authority, Tito got involved in manipulating people playing with their weaknesses and fears. He would assure them by saying: "After all, your house is bugged too."18 On the eve of June $16^{\text {th }}, 1966$, before the session of the Executive Committee KPJ, "Tito", Kardelj, Bakarić and others "assured" most of the Party members, in a similar manner. Although the wiretapping was common practice and was totally legal and controlled by the top-level Party leaders, the whole affair caused a lot of suspicion among them. Svetozar Vukmanović alias Tempo claims that Tito showed him the wires in the house and in his bedroom. Tempo at first did not believe Tito's allegations and was totally bewildered with what he saw. Jovo Kapičić claims that Tito was noticeably shaken when he invited him for a talk. Tito was adamant that Ranković was preparing a coup. Moreover, Tito insisted to show him his bedroom where, allegedly, the listening devices were installed. ${ }^{19}$ When Tito, 14 years later, received General Lj. Đurić, his former close associate who was ousted after the Sixth Congress, he also showed him "how Marko eavesdropped on him". Đurić, however, reminded Tito that the devices were fixed during his time with Tito. On this remark tension eased and Tito changed the subject and said: "Eh, Đurić! ... And I should tell you, you know ... there was a plan for your

17 Kovač, Dimitrijević, Popović, op. cit., 87-89.

18 Lukić, op. cit., 30-31.

19 Testimony by Jovo Kapičić, Crveno i crno, TV Document, 11. 4. 2008; Lukić, op. cit., 32. 
liquidation while you were in prison! I saved you! I did not allow it ... We are both alive and well. It's all that matters." ${ }^{20}$ Edvard Kardelj went even further; he had suspicions that Ranković engaged Antun Vratuša to follow him. ${ }^{21}$

At this session, for the first time, it was officially announced that Tito was wiretapped. A commission headed by Macedonian party leader Krsto Crvenkovski was established to substantiate charges made against Ranković and members of the Commission included representatives from each republic including Đuro Pucar, Blažo Jovanović, Miko Tripalo, France Popit and Dobrivoje Radosavljević. Ranković offered to resign from all the posts to enable undisrupted investigation, which was accepted. At the CK SKS session on June $23^{\text {rd }}, 1966$ it was decided that Vojin Lukić should no longer perform his duties as Secretary of SSUP and as Secretary of CK SKS until the investigation was complete. When, on the eve of the Brioni Plenum, Ranković and Gošnjak initiated a meeting with Tito in his cabinet, Tito had dark glasses on, which Ranković took as an ominous sign. Conversation was cold, and when Ranković stood up to leave, Tito said that he did not need to see it all that tragic and added dryly at the end, "Mind you, we'll still cooperate."22

As the source for discussion at the Fourth Plenum (Hotel "Istra", Brioni, July $\left.1^{\text {st }}, 1966\right)$ two documents were used: confidential Documents and Committee Report, which was published and read at the plenary session.

Documentation had incriminating four-point evidence mostly based on the wiretappings from which conclusions about deformations and abuses of the Security service and the roles of Ranković and Stefanović therein were made. ${ }^{23}$ According to Lukić, as evidenced by S. Numić

20 Boro Krivokapić, „Samoubistvo šefa kabineta“, feljton Beskonačni Tito 5, Večernje novosti, 5. 2.2008.

21 Biografija Josipa Broza Tita nepoznatog autora iz zaostavštine Milana Đokovića Popa, unpublished, author's possession.

22 Similar words, Tito used with Đilas, then Nikezić and Latinka Perović, Tripalo and others when they have already been defeated. Lukić, op. cit., 33-37; Dušan Čkrebić, Pogled iskosa, (Beograd, 2009), 175.

23 The first relates to the microphones installed in No 15 Užička Street, on the desk in the study, which was connected with a cable to a tape recorder placed in a book cabinet in the library next door (which was built much earlier). The second one was installation of a PABX system with phone devices in the rooms and that one phone device was installed in the bedroom of Jovanka Broz. Finally, there is mention of other bugging devices and recorders, in the apartments of the party leaders Slavko Komara, Moma Marković and others. The installation was the responsibility of a technical dep. 
and A. Duhaček, all wiretapping installations were set legally, following the decision of the highest political leadership officials and Tito personally in 1961, on the eve of the Conference of Non-Aligned Nations. Its purpose was to eavesdrop on non-aligned leaders who resided in the villas of the party officials in the Dedinje district, Belgrade. All the republic services participated in this action including DSNO, SSUP and SSIP, which were personally praised by Tito and there was extensive technical and other documentation on it. Later, the lines went "dormant" but Party officials who occupied these houses were never informed about that, or about their placement. Interestingly, the file was declared a state secret and was distributed to plenum participants just before the session. However, its copies were seized when the session was over regardless the fact that its publishing was meant to compromise Ranković and Stefanović. This can be explained by the fact that the evidence was pretty week for publishing, let alone leave to members of the CK for scrutiny and crosschecking after the Plenum..$^{24}$ In his notes, Ranković writes that the Head of KOS Dušan Rusić testified that no military-technical commission had ever confirmed the evidence of wiretapping. ${ }^{25}$

The Commission report was made public and contained information on the situation and methods of work of the State Security and responsibility of the highest officials, primarily Ranković, who, allegedly, entirely placed the Service "under his wing". He underlines that the society after a period of revolutionary struggle and transformation went through democratization, which "security organs due to the conservative resistance of individuals were not able to follow." ${ }^{26}$ The Service went out of control and as "a force above state" served the "conservative forces gathered around Ranković and Stefanović" and took control of the Party, economy and social life through the involvement in the personnel and organizational issues, abusing personal records, investment issues, etc.

A wide network of informants in the Party was created and stateof-the-art spy technology was used on wiretapping officials. Citizens were exposed to unfounded intrigues; there were massive breaches of

of the Military service. SSA technician V. Đorđević was also involved. (Later under investigation by art. 105, disclosure of state secrets) for which the entire SSA was later charged. Lukić, op. cit., 43-70.

24 Lukić, op. cit., 43-70; Duhaček, op. cit., 222.

25 Ibid.

26 AJ, VSJ, 212, f. 18, Izveštaj o deformacijama u radu Službe državne bezbednosti, 12. oktobar 1966, 1-40. 
citizens' rights (breach of privacy, secret letters and other means of communication).

In the conclusion, the Commission report gives following recommendations: reorganization of the State Security, the Secret police no longer be used for political purposes, ousting of Svetislav Stefanović and his expulsion from the CK SKJ and SKJ, Aleksandar Ranković's resignation was accepted; the State Commission was to continue with the investigation and naming names in the affair and to bring them to justice. However, in the second report, at the end of 1966, Commission suggested that further prosecution of Rankovićs group be abandoned because of their "past merits for the country". ${ }^{27}$ The only official who opposed the Commission was Service's Head of the Human Resources, B. Novaković. He remarked, "How comes, all of a sudden, such assessment of the UDBA work and about all of us who have been with the Service for so many years? Until yesterday we were receiving decorations and now this? Allegations made by comrade Crvenkovski that we have become force above the state and society and that we are in charge of the Party are untrue."28

Not only was the wiretapping affaire linked to Ranković and his associates centre piece in the Report, they were accuses of many other things. One of the most frequently mentioned is "control of privacy" of senior officials. Besides Tito and his wife Jovanka, their regular targets were Milka Kufrin and Stanka Veselinov. Milka Kufrin, Minister of Tourism and member of the Federal Executive Council (SIV) was wiretapped because she allegedly had an affair with her chauffeur, whose wife found out and threatened with a scandal. Wiretapping had no immediate effect, so one of the UDBA officials, Slavko Glumac, found out in a personal contact with the chauffer and his brother that the rumours were true. At the time, the Consul in Munich was S. Krstić Uča who confirmed that Milka requested a residence permission and work permit from the German authorities for the driver. At first, the driver claimed that he was forced into the relationship being threatened that he would be punished if he refused but later denied it saying that he was forced to such confession under the pressure from the Lukić's office. Based on these allegations, Milka was dismissed from the office and reprimanded by the Party. This affair

27 AJ, VSJ, 212, file 18, Izveštaj o deformacijama u radu Službe državne bezbednosti, 12. oktobar 1966, 1-40; Izveštaj o protivustavnoj delatnosti Aleksandra Rankovića i zloupotrebi SDB u političke svrhe 1. decembar 1966, 10-16.

Lukić, op. cit., 43-70, Selim Numić, Dobra zemljo lažu, (Beograd: IRO Nova knjiga, 1989 ), 95. 
was later used as an example of abuse of the Service. ${ }^{29}$ Another public affair involved Stanka Veselinov. The affair triggered many rumours, malicious remarks and recounting in the city couloirs. The wife of Jovan Veselinov was prone to love affairs and had many protégés whose careers she openly helped using her status and skills in abundance. She was also known as alleged collectionner of antiques, paintings, rugs and objects of great value from the committees, councils and other public institutions. She would later sell those items to resellers at an enormous price. Many prominent Party leaders including Ranković, Stambolić, Penezić and Dušan Petrović alias Šane tried to come to the bottom of this case for years. UDBA hired a team, led by Milan Đoković alias Pop, to work on this case. The surveillance showed that Stanka was often seeing a young poet Matija Bećković, who worked for the Jež magazine. They often met at an apartment in the Belgrade district of Topličin venac, which was owned by an employee of the Municipality of Stari Grad. The apartment was wiretapped by UDBA. During those meetings the incriminating recordings were allegedly collected. Except the intimate details, recordings testified of Stanka's "anti-socialist views", mocking of the Party officials, socialist self-management, and even Tito and Jovanka (they jokingly talked about assassination on Tito, etc.). ${ }^{30}$ Ranković's team agreed that, if the recordings were to be used as evidence against Stanka, the best way was to present them as material obtained by following Bećković as a politically dubious character, descendent of a "public enemy" (his "Chetnick's origins"). Therefore, their relationship would have been discovered by accident. The reason for the cover up was to spare Žarko Veselinov from being hurt and to avoid any insinuations of an attempt to deliberately compromise him. D. Petrović Šane, President of the Serbian Parliament, was satisfied with the success of the action. He awarded the operatives

29 There are interpretations that Ranković, for security reasons, opposed liberalization of travel, something, the federal Minister of Tourism Milka Kurfin insisted on, which would raise tourism revenues and thus improve the negative foreign trade balance. This conflict and the subsequent scandals were rated as the calculation of liberals and conservatives within the SKJ. Same views were about Tito's decision to deal with Ranković. The idea was conceived while he was travelling back on the "Blue Train" to Belgrade. Ridli, op. cit., 346; Lukić, op. cit., 43-70.

30 Stanka Veselinov allegedly gave an UDBA document to Bećković about Bećković and other writers from Belgrade and Novi Sad, which she allegedly took from her husband's briefcase. When he learned that her phone was wiretapped, she told Bećković, who could not help wondering how it was done and he was embarrassed because he felt responsible for the safety of the apartment which he found. Lukić, op. cit., 80 . 
with the sizeable cash rewards. Only a year later they were tried for misuse of the Service. The wiretapping operation went on for almost three years and many Party officials were aware of it including S. Penezić, D. Radosavljević, S. Doronjski, P. Stambolić, etc. However, after the Brioni Plenum the affair was presented as a set-up and that even Bećković was planted by UDBA, Ranković was accused and Stanka played victim to the UDBA intrigue and returned to her husband Žarko. In the same context it was referred to Mehmed Hodža case, former Minister, whose phone calls had been intercepted since 1954 under suspicion that he kept contact with saboteurs from Albania via his nephew. No action against him was taken because the evidence obtained from the Service was not reliable. Ismet Šaćiri, Vice President of the Socialist Alliance of Serbia was also under the surveillance which was requested by the Party and State Authorities on suspicion of raping an underage cousin. The Party Commission headed by D. Petrović and Vice-Premier of the Republic Executive Council (RIV) S. Penezić ordered the wiretapping, but Šaćiri was freed of the accusations and his reputation restored as a victim of abuse of the Security services in $1966 .{ }^{31}$

Wiretapping of the office of M. Mišković was also in the spotlight in the context of wiretapping officials. The microphone and tape recorder were installed during the time of S. Stefanović and were, as a part of standard business practice, used to record meeting minutes and discussions during the Board (Collegium) meetings. Later on, there was also mention of monitoring and surveillance "of the Vojvodina officials", mostly of Croatian and Hungarian nationality (G. Tikvicki, L. Rehak, F. Nandor, and J. Nađ) and Party activists who were arrested by the Hungarian forces during the occupation. Under the magnifying glass were also "deaths in the prisons in Kosovo". ${ }^{32}$ It is interesting that all the wiretapping scan-

31 Slobodan Penezić Krcun reportedly said that he believed that the control was unnecessary because "he wouldn't kill himself, nor would he flee from embarrassment because if he was an honest man, he would not do that to a child, and especially not to a child of his relative. Especially to an orphan." Lukić, op. cit., 77.

32 Increased mortality in prisons in Kosovo has been a de facto situation, but also the fact was that prisons were getting overcrowded and incomparably worse hygienic conditions than elsewhere, and that the Albanians did not have the opportunity because of poverty to receive frequent and abundant food parcels, so they were usually dying of tuberculosis. Increased mortality of Albanians, after all, was the reality in other prisons, primarily KPD Niš, which was relatively high until the construction of the KPD in the East in the late 50's. Velimir Đokić, Robijanje demokrate, književnika i akdemika Pekića, unpublished manuscript in the possession of the author. 
dals and allegations of the human rights violation related to managers and bureaucrats (Veselinov, Kurfin, Šaćiri) or the Albanian minority, and that there was no mention about repression against ordinary citizens, which dominated during 1944-1966.

In his speech at the Brioni Plenum, Tito stressed that the Plenum was continuation of the extended session of the Executive Committee of March 1962, which, according to him, failed "due to the compromise tendency not to affect the unity of the Party and the unity of our leadership that in fact, was already violated." ${ }^{33}$ According to him, deviations in the work of the Service began even before 1957 (the official report leaked out only by mistake after 1964). "Comrades, we have made a mistake, to have our national security to itself for more than 20 years, and because of our enormous confidence in comrade Ranković and the Security services, at our Executive Committee we never questioned the work of the Service." Tito assessed that, in the case of Ranković, it was about a fractional group which struggled for power and that further investigation must move in that direction. After the Committee Report, Ranković took to the floor first. However, his presentation was pale and unconvincing. ${ }^{34}$ Ranković's presentation and defence during the plenary session disappointed even his sympathizers. Until the end, it remained unclear, as in case of Đilas twelve years earlier, what were the motives behind his weak presentation during the Party condemnation, and six years later the behaviour of Nikezić and Latinka Perović, Tripalo, Dapćević and others. Was it respect for Tito, the Party's ideology to which they belonged, psychological unpreparedness or fear and concern for themselves and their families as they knew the inner side of the mechanisms of terror?

After the Ranković's speech, political and military officials took stand respectively. They all condemned Ranković and his associates for

33 Shortly after this meeting, Tito in his famous speech in Split on May 6, 1962, on the occasion of commissioning of the hydroelectric Omiš, harshly criticised the entire Party leadership for political mistakes and weaknesses in the work, abuse, privilege, corruption and other malfeasance in the economy. Momčilo Zečević, Početak kraja SFRJ - Stenogram i drugi prateći dokumenti proširene sednice Izvršnog komiteta CK SKJ, (Beograd, 1998), 16.

34 "I thought, and I was absolutely convinced that he as the accused, knows quite well and in detail the materials and what he is guilty of and I could not understand why he does not more energetically denies it (...) His strange defence strategy at the Plenum led me to believe that there may really be some guilt and that the real reason for his removal which his prosecutors have not mentioned" - recalls Vojin Lukić who as a possible justification finds an alleged heart attack which Ranković had on the eve of the Plenum when he received the materials. Lukić, op. cit., 88. 
political conspiracy. Most of them believed that even "Ranković's followers" believed that they were in some kind of "voluntary misapprehension"; others, in their overzealousness, went above Tito's views driven by personal or political intolerance against Ranković and his ideology. First speech was delivered by General V. Kovačević, followed by C. Mijatović, S. Vukmanović Tempo, M. Minić, J. Veselinov, and V. Popović. The last three spoke with hatred and revenge. ${ }^{35}$ General Ivan Gošnjak was advised not to attend the Plenum. He was told, "You do not know what's coming! You couldn't take it!" Therefore, he did not speak at the Fourth Plenary session for fear that Counter Intelligence Services (KOS) may also be under scrutiny. ${ }^{36}$

What the atmosphere was like during the session is best described by Vojin Lukić, Ranković's sympathizer and associate, who declined to speak. "I refused to speak because I had neither the strength nor the will to challenge the motion of the entire CK. I couldn't come to my senses from the shock after reading the documents last night", he said. Contrary to Lukić, S. Stefanović kept a firm stance and denied that the Agency illegally wiretapped senior officials. During his speech, he was sharply interrupted by S. Vukmanović Tempo, who yelled, "You're lying! You've bugged me!" Lukić replied, "No, never, except, perhaps, in the case of Đilas. But, no, not even then, because Đilas was bugged, so we heard your conversation with him." ${ }^{37}$ He was then interrupted by C. Mijatović,

35 The reasons for this were as follows: According to Ranković, he was in disgrace with Tempo since 1940, because he brought Blagoje Nešković to PK Serbia, instead of him, as suggested by Đilas; Veselinov was mostly due to the scandal with Stanka Veselinov, and Vlado Popović, apparently, because after the withdrawal from the Central Committee of Croatia, he was not posted to a higher position. Lukić, op. cit., 92.

36 The only one who stood up to Tito, partly because of the political liquidation of Aleksandar Ranković, was State Secretary for National Defence, General Ivan Gošnjak. Marshal immediately made clear that he should look for his replacement and allegedly ordered him to accompany Ranković in a military plane on his way to Brioni. The announced criticism of the KOS never happened because in September 1966 Proxy CK SKJ in the JNA brought unambiguously clear conclusions regarding the Brioni Plenum: The security agents of the JNA had nothing to do with abuses in the highest ranks of the national security, nor with such deformations due to which the state security tried to turn into a force above society. Things like that could happen in the JNA because it has been managed for twenty years by the most responsible seniors ... In the system of command and subordination of the JNA security organs they couldn't rise to power over the command. Lukić, op. cit., 91,128.

37 Milovan Đilas was tapped by the decision of the highest political authorities, on the eve of the Third Plenum of the Central Committee, which discussed the Đilas case; Tempo then phoned Đilas and told him that he fully agreed with him, with all his 
who said, "It seems you've covered up the faux-pas of Slobodan Šakota in Moscow." C. Mijatović, then explained, that Šakota was Assistant to the Minister of Foreign Affairs when he was Ambassador in Moscow who spoke to him in confidence of his appreciation of Ranković over Kardelj; he also used to gossip about the top government officials in the Government of Bosnia and Herzegovina. Ranković, obviously, approved of such stories therefore Šakota was not reprimanded. ${ }^{38}$ S. Stefanović denied these allegations, claiming that "the Šakota case" was dealt with by the Party Personnel Committee led by Velimir Stojnić. ${ }^{9}$

The Brioni Plenum was well organised. The potential “Ranković's followers" were distinguished from others and under surveillance by the KOS agents. General Petar Babić, who was the Head of Tito's military office until 1966, was conveniently dressed in civilian clothes and was seated next to Lukić to prevent any potential danger to Tito from him. Similar security arrangements were made for Ranković, Stefanović and few others. ${ }^{40}$ An experienced UDBA officer, Branislav Pendić recalls that the entire UDBA line-up was under surveillance by the KOS operatives in days prior to the Brioni Plenum. Ranković's people were "covered", and the UDBA operatives were monitored by Ivan and Milan Mišković, military and civil security services agents. That the situation was at a boiling point was confirmed by the fact that during the Plenum even the army forces were on standby and parts of the Guards division were brought to protect access to Belgrade. There was fear that the clash with Ranković may escalate into a full scale Serbian political coup. Although the IK CKS report states that "in explaining these problems to other republics, impression of problems concerning personnel, security and society in the Socialist Republic of Serbia must be avoided", hunt of Security personnel

views and promised him unconditional support. That conversation was recorded and immediately delivered to Tito who called Tempo the same evening. The next day, Tempo was among the first to speak and sharply attacked Đilas. Lukić, op. cit., 95.

In the testimony before the commission Mijatović has even claimed that Šakota openly said that Tito was too old and should withdraw, and that Ranković should come in his place. Moscow evening become focus of attention and in particular its part where a drunken Soviet Part leader allegedly glorifies Ranković as the future president. Lukić, op. cit., 95; Kirbus, „Moskovska zdravica za Rankovića”.

39 Mijatović, according to Stefanović, apparently, was the inspirer of the false news in Bosnia about Tito withdrawing from politics and Ranković succeeding him, which was supposed to come to the Broz and contribute to his suspicion and resentment towards Ranković. Lukić, op. cit., 113. 
was conducted only in Serbia. ${ }^{41}$ It was difficult to swim against the main current since the Communists were raised in the spirit of unity of action and fostering the cult of Tito. Vojin Lukić later confessed, "When I saw that everybody voted for the proposed decision, I raised my hand too and voted for it. I acted against my conscience and contrary to my belief." 42

At the Plenum, five recommendations were adopted: 1) to reorganize Federal Security personnel in accordance with the new social orientation; 2) to obtain approval from SIV for the Commission to further investigate and persecute the culprits; 3) to deprive Svetislav Stefanović, responsible for the operation of the Service of all party and state functions and expel him from the Party; 4) to accept Aleksandar Ranković's resignation from all party functions and from the post of Vice President of the Republic (exclusion from the Party was not immediately proposed for tactical reasons and was done to bide time to prepare public for it) and; 5) to declaratively invoke the Communists and the people to stay on the path of democratization and the development of self-management in the wake of the Brioni Plenum decision. In the final say Tito, in a familiar manner (as with Đilas before and later with the liberals), paid Ranković tribute for his "good behaviour" and expressed hope that such is expected from him in the future, and expressed even possible cooperation. The fact that the Croatian Secretariat for Internal Affairs "destroyed tape-recordings from the Fourth session of the Central Committee at the beginning of 1970 makes an interesting observation." ${ }^{43}$

After the Brioni Plenum, Aleksandar Ranković definitely retired from public life. He retreated to his villa in Dubrovnik far from the former comrades. He enjoyed his family life and indulged in fishing. Although he remained loyal to Tito and the Party to the end, he did not take any public or illegal activities against the regime. No other specific "hostile activity", besides the political qualifications, rumours and allegations of spreading étatistique and anti-reform slogans, could have been attributed to him until his death. There are brief remarks in the State Security Services records about him: "Since the abolition time in December 1966, actions of Aleksandar Ranković and members of his group were limited to destruction of the traces of their activities", claiming that "time will

\footnotetext{
$41 \quad$ Ibid., 35.

42 Ibid., 126.

43 AJ, Centralni komitet Saveza komunista Jugoslavije (Central Committee of the League of Communists of Yugoslavia - CK SKJ), 507, IV/96, prilog 9; Pero Simić, Svetac i magle, (Beograd: Službeni list, 2006), 193-194.
} 
tell of his innocence", with slanders to "discredit some party leaders" and presenting themselves "as legitimate representatives of the Serbian nation," which "babbitry society accepts and spreads." ${ }^{44}$ On May $12^{\text {th }}, 1967$, Tito held talks with a delegation of civil and military security services when he was told that "Ranković did not realize that he was wrong", but still thought "thing were different". Then, Tito said, "I am of the opinion that he has limited intelligence, but is very cunning."

Distancing from Ranković after the Plenum went to such an extent that there were examples of group photo retouching and cropping sequences of newsreels to cut him out. ${ }^{46} \mathrm{He}$ died of a heart attack on August $19^{\text {th }}, 1983$, on the hotel terrace in Dubrovnik. His funeral was an unorganised mass-gathering which was attended by around 100.000 people, which speaks more of his reputation and popularity and less of the national euphoria, the political moment and the frustration Serbs felt because of their endangered national status after the constitutional reforms in the 70s, which "Ranković's unitarism" recognized him as the protector of Serbian interests in Yugoslavia. ${ }^{47}$ In spite of the dismissal and political convictions, Ranković is still, in Serbia and within the variety of Communist circles and the people, perceived as a sincere fighter for the unity of the country, the protector of Serbs, fighter for social justice and honest revolutionary, the guardian of partisan ethics and steadfastness. ${ }^{48}$

$44 \mathrm{AJ}, \mathrm{VSJ}, 212$, f. 18, Analiza o sprovođenju Osnovnog zakona o unutrašnjim poslovima, 9. decembar 1967, 28.

45 AJ, Kabinet predsednika Republike (President's Office - KPR), 837, II-2, k. 54; Pero Simić, Raspeto Kosovo, (Beograd, 2006), 188.

46 "I remember that on May $25^{\text {th }}, 1974$, when I arrived, he had already read all the newspapers of that morning, and with resignation showed me that the media published articles commemorating the great partisan battle, 'Landing on the Drvar River', and that none mentioned his name. Even the photos of him had his name erased." - recalls historian Dr. Venceslav Glišić who has repeatedly spoken to him. „Seks afere rasturile Jugoslaviju“, Revija 92, No. 652, 2.1.2009.

47 It was originally planned that he is buried here when his body is transported from Dubrovnik to Belgrade. General Sreten Kostić vigorously opposed to it and said that Ranković's place is in the "Alley of the Greats" at the New Cemetery in Belgrade. It is interesting that the city of Kraljevo and the town of Banatski Karlovac, which were named after him "Rankovićevo" and "Banatsko Rankovićevo", already in 1955 returned to their old names. This was in accordance with the new law, which forbade places to bear other names but Tito's.

48 Immediately after the plenary session official reports record that awkward questions could be heard: "how comes only leaders from Serbia are being removed". Constitutional changes that were largely perceived as the "break up of Serbia" (to which he, ap- 


\section{Showdown with the "Ranković clique" after 1966}

After the condemnation of Ranković at the Plenum, the State Security Service (SDB) introduced a new category of internal enemies "Rankovićevci (Rankovićism)" described as "bureaucratic-dogmatic power, bureaucratic centralists, Unitarians" who advocated dogmatism and etatism, and condemned self-management as destructive and similar. They reportedly refused to confess their guilt for wiretapping of government officials saying that it was a farcical show cooked up to remove loyal Serbian personnel from SDB and state authorities. Although the Brioni Plenum resonated in other republics in terms of reorganization of services (reduced jurisdiction of the federal departments and its decentralization) and audit of documentation, however, its main result was a complete restructuring of the Security services in Serbia. After the Brioni Plenum, there were replacements, early retirements and the arrests of people suspected of sympathizing Ranković and his associates, mainly of Serbian nationality. V. Lukić and S. Stefanović, Service's leading men were marked as the most responsible for the abuse of the Service, even more than Ranković himself. There were also many lower level officials on the list. Soon after, at the VI Central Committee plenum on $15^{\text {th }}$ September, 1966, as proposed by S. Cana Babović, Ranković was finally excluded from the Central Committee of LSS and in October, he was also expelled from the League of Communists. However, there was no trial because of very inconclusive evidence (despite the pressure on members of the Service to falsely testify). Though Ranković "knew much" and could reveal much at the possible trial, there was strong desire to preserve the "democratic reputation" before the rest of the world. Provincial Committee of Kosovo quickly replaced Jovo Šotra, Sekulović and Kadri Reifijn. Exposé of V. Deve, Dž. Nimani, A. Šukrije and others at the Fourth Plenum officially announced the beginning of a fierce campaign against the UDBA and Ranković on the basis of "nationalism and Serbian chauvinism against the Albanians."

parently opposed and which were one of the main reasons for his dismissal) have further contributed to his popularity among the people. Expansion of Albanian and Croatian nationalism, rousing of social inequality and crisis of communist ideology in general, contributed to the increase in the number of the "Ranković followers". His burial, therefore, turned into a silent protest of people dissatisfied with the political situation, the decentralization of Serbia, the Yugoslav confederation, the proliferation of nationalism and separatism, as well as the growing economic crisis. Lukić, op. cit., 133. Integral official report The Political situation in Serbia after the IV session of the Central Committee and the activity of the League of Communists of Yugoslavia is cited. 
An immediate broad investigation campaign of the special committees of the SSUP (Federal Secretariat of Internal Affairs) and SUP Serbia began with criminal investigation of the organs of the Military and District Courts in Belgrade, which sought to obtain evidence for Ranković's criminal conviction and some staff and officials of the SDB (Federal Security Services). At the initiative of E. Kardelj, Državna komisija za ispitivanje zloupotreba (National Committee for Investigation of Abuses of the Service) was formed within UDBA, to gather evidence from all over Yugoslavia on abuse of the secret service as soon as possible. The President of the Committee was R. Lazarević; other members included editor of the Borba newspaper, P. Ivačić, editor in chief of the Tanjug, M. Jovanović, a journalist of the Federal Secretariat for Information, P. Stojanov, SSUP associates, 0 . Ružić and $Đ$. Miljanić. They were later joined by the Federal Minister Milan Mišković, who opened the UDBA archives for research and requested information on the work of the secret services, especially Ranković, from the ministers of the republics and the police. UDBA in Serbia was controlled by KOS (Counter Intelligence Services) of JNA (Yugoslav Army). The Republican Party Commission headed by Danilo Kekić was formed on July $5^{\text {th }}, 1966$ with a mission to collect material for the conviction of Ranković at the SKS (League of Communist of Serbia) at the Fourth Plenary session. Ranković was blamed for seizure of weapons in Kosovo and Metohija, smuggling and cigarettes trafficking, Goli otok affair and the affair of import of 195 electric locomotives from Sweden. ${ }^{49}$ Beside the confiscation of weapons from the Albanians, there was a mention of the increased mortality in prisons in Kosovo, Prizren trial process, wiretapping of the Minister of Forestry Mehmet Hodža (for the suspicion of being the Sigurimi agent) and Ismet Šaćiri, Vice-President of the League of the Socialist Working People of Serbia, accused for the rape of a minor and because of the problem of exile of the Turks to Bosporus during the $50 \mathrm{~s}$ etc. ${ }^{50}$

49 Croatian political leaders were in favour of the "Swedish" locomotive versus "French" which were better and cheaper, which were favoured by the management and unions of the ŽTP Beograd and other factories. Lukić, op. cit., 22.

50 The report of the Federal Public Prosecutor also mentions the use of force and torture in the "Morava" operation (finding the archives, gold, securities and other valuables belonging of D. Mihailović on the territory of the Ovčar-Kablar Gorge 1965). Then the political liquidation of Predrag Ajtić, the ambassador in Sofia for his critical remarks on foreign policy of Josip Broz that was before the officials of the Embassy in Sofia and other well-known materials on wiretapping Tito, Kardelj and other leaders organized by Ranković. AJ, VSJ, 212, Izveštaj o protivustavnoj delatnosti Aleksandra 
Vojin Lukić, Srba Savić and other associates were put under pressure by the investigating commissions and the Secretary of the Interior, Slavko Zečević to testify and provide compromising material on abuse of the Service. ${ }^{51}$ Slobodan Krstić Uča, previously a senior UDBA official, was also pressured, but since no evidence was found, he was sent to premature retirement from the Service; Lukić's brother, Milisav, deputy secretary of UDBA, ten days later was released and soon left the Service $^{52}$ There was also an attempt to prosecute Lukić for misuse of the material evidence from the confidential archives. His role in the secret export hideout in Rijeka, which continued to operate well even after its formal abolition in 1963, was also under scrutiny. It turned out that he had no role in it. The operation was conducted by Edi Brajnik and Branko Damjanović. All classified documentation on Service abuses that was used at Plenum was from a room in the Central Committee building in New Belgrade and was open for public viewing. Vojin Lukić was also criticized for a note in his report on a remark regarding Tito's absence made by Thessalonica soldiers who were present during the $50^{\text {th }}$ anniversary celebration of the Battle of Cer in Tekeriš in 1964. The soldiers commented that Tito was attending the Alka of Sinj event instead. The event was attended by only one Party leader, the Mayor of Šabac. The media has not covered the event probably to avoid a potential harm to Tito's reputation. As the result of all this, Vojin Lukić, Srba Savić and some other members of the SDB and the police were suspended and excluded from the Party and criminal procedures were soon initiated against them. Consequently, 714 employees, operatives and senior staffers in the federal police lost their jobs after the reorganization. ${ }^{53}$

Despite the main charges against them, A. Ranković and S. Stefanović were not prosecuted because of the political immunity they enjoyed. In October 1966, the authorities in Belgrade began criminal pro-

Rankovića i zloupotrebi SDB u političke svrhe 1. decembar, 1966, Optužnica protiv 16 radnika SSUP-a Ktr. br. 713/66, 1-19.

51 Mark Lobi, Tajne službe Srbije, (Beograd, 2001), 203-205; Lukić, op. cit., 100-101.

52 Lukić said that his brother Božidar was also interrogated in the "conveyor style" (they gave him food and water, but he was not allowed to sleep), in order to prove that the "Ranković's group" may have had a "foreign-spot". Lukić, op. cit., 194.

53 "We started slowly to send people to early retirement. UDBA staff were depressed because most of them worked responsibly, believing that their work was in the interest of the society". Slavko Zečević, Sećanja i kazivanja, (Beograd, 2004), 213; Mark Lobi, Tajne službe Srbije II, (Beograd, 2001), 183-199; AJ, Savezno izvršno veće (SIV), 130, 558, br. 2588, 19. novembar, 1966. 
ceedings against 16 people, including Vojin Lukić, former Minister of the Federal Police; Životije Srba Savić, former Minister of the Serbian Police; Milisav Lukić, Deputy Secretary of SSUP; Selim Numić, Assistant Secretary of SSUP and Head of the Department for Escorts and Interception; Pavle Tepin, Director of the Technical Institute SSUP; his assistant Vojislav Baldžić; Boža Arnautović, Head of the Operations and Technical Department of UDBA; Mirko Trivić, Assistant of the Head of the SSUP of the Fourth Directorate; Živorad Paunović, SSUP technician; Stanislav Pavlin, Ass. Director of the SSUP Technical Institute, Velimir Đorđević, technician of the SSUP of the Fourth Directorate; Aleksandar Ignjatović, retired UDBA employee; Milan Đoković Pop, Chief of the UDBA Belgrade; Slobodan Jovović, Assistant of the UDBA Belgrade Chief; Gvozden Predojević, Chief of UDBA Belgrade and Zvonimir Radošević, Chief of the Belgrade Secret Police. The accused were arrested between June $29^{\text {th }}(\mathrm{V}$. Đorđević) and the end of September 1966. Several of them were held in custody for almost three months (Numić). ${ }^{54}$

The exact insinuations and affairs relating to the wiretapping of officials, creating scandals and abuse of Service were in the indictment signed by the Federal Public Prosecutor F. Hočevar. Only Stanislav Pavlin from Slovenia confessed. He claimed that he wiretapped E. Kardelj at the behest of Numić..$^{55}$ Vojin Lukić was initially suspected of the offense of abuse of official position (art. 314), forgery and destruction of official documents (art. 319) and the disclosure of official secrets (art. 320). The defendant was represented by M. Jovanović Lale and his conduct during the hearing was qualified as decent. By the court ruling of November 22nd, 1967, V. Lukić and his collaborator S. Savić were remanded in custody. The federal public prosecutor's ruling, previously qualified as a criminal offense, now under the Articles 100 and 105, qualified it as "a crime against the people and state", which the above named were plotting "to unconstitutionally take power". Selim Numić, who was the Chief of the Technical Department of the $4^{\text {th }}$ UDBA Division and since 1963 Assistant

54 AJ, VSJ, 212, Izveštaj o protivustavnoj delatnosti A. Rankovića i zloupotrebi SDB u političke svrhe 1 . decembar 1966, Optužnica protiv 16 radnika SSUP-a, Ktr. br. $713 / 66,1-3$.

55 Even the collection of data on MPs in Serbia and councillors in Belgrade was described as conspiracy of the UDBA and Ranković. Pavlin later visited S. Numić at his apartment and asked him for forgiveness, because he, as the Slovenian, was under particular pressure to confess the alleged wiretapping - see: Numić, op. cit., 22-23; AJ, VSJ, 212, Izveštaj o protivustavnoj delatnosti A. Rankovića i zloupotrebi SDB u političke svrhe 1. decembar 1966, Optužnica protiv 16 radnika SSUP-a, Ktr. br 713/66. 
to the Federal Secretary of the SSUP and who lost three brothers during the war, got the worst end of the stick. He fell seriously ill and spent several months in the prison hospital where he lost 40 kilograms, but still refused to give false testimony and lay blame on anyone. ${ }^{56}$ Due to such behaviour of the accused Numić and others and for political implications that the court process could arise from, the general abolition of the accused was delineated. However, by the end of 1966, they were all fired, sent to retirement and excluded from the Party. The only ones who were spared for their loyalty in the process were M. Lukić, Deputy Secretary of SSUP; Milan Mišković, who was later promoted to Deputy Governor of the National Bank and Dušan Lazić. Although the Chief of the Fourth Davison until the Brioni Plenum, Lazić was transferred to the Technical Department and was later promoted to colonel in the Army. ${ }^{57}$ Ranković and Stefanović were not questioned according to the charges, which was violation of one of their basic rights - the right to defend themselves. They were protected by their parliamentary immunity (Art. 202 of the Constitution of the SFRY); therefore, it was suggested to the SIV (Federal Executive Council) to approve the initiation of criminal proceedings, which never took place. ${ }^{58}$

Based on the report of the Federal Public Prosecutor, the SIV has prepared a report for the Assembly, which gave general, repeated instances of abuse without citing any new evidence. Therein, the group was advocating "firm hand against democracy" and similar, and was detrimental to the development of international relations, "especially in areas inhabited by the members of certain nationalities" and "slowing down of the development of self-management". Paradoxically, in the end, after all these serious charges, the defendants were given recommendation for amnesty, which can only be explained by political reasons and unsubstantiated evidence. ${ }^{59}$ Avdo Humo gave an exposé on abuses by the UDBA on behalf of the SIV before the members of the Federal Assembly and after a short debate in which Maksimlijan Baće and Mile Milatović stood

56 "I'm ready, Milan, to hung in the middle of Terazije if you find that I have in any way abused the Service, Well... Are you crazy? ... Are you drunk? Have you lost your mind? The Service to eavesdrop on Tito? Man, do you know that everyone of us, from the Service, is ready to die for Tito? Are you aware of what you've done and what sin you've committed against us, the entire Service and this country?"- S. Numić's emotional outburst during his visit to Milan Mišković. Numić, op. cit., 22-23.

57 Numić, op. cit., 22-23.

58 AJ, VSJ, 212, Izveštaj o protivustavnoj delatnosti A.Rankovića i zloupotrebi SDB u političke svrhe 1. decembar 1966, Optužnica protiv 16 radnika SSUP-a, Ktr. br. 713/66, 1-19.

59 Lukić, op. cit., 279-297. The report of the Federal Public Prosecutor is cited. 
out in the attack, the recommendation for abolition passed. No further repressive measures were taken against the accused. They were fired, sent to an early retirement and had difficulties obtaining passports. Tito openly announced the abolition in early December in 1966 at a seminar for leading legal experts giving directives to the Courts. ${ }^{60}$

Persecution of the "Ranković cliques" in the late '60s and early' 70s came just in time of the ousting of the Serbian liberals forewarning the public that even Unitarians can expect massive persecutions if they were too loud. This meant another confirmation of the existence of political symmetry in persecution, this time it was between "Anarcho-liberals and Unitarians" within the Party. Ousting of the "Ranković cliques" and the condemnation of abuse of the UDBA, Party intended to acquire democratic legitimacy in the domestic and foreign public. However, decentralization and constitutional changes toward greater federalization lead towards victory of the "Federalists" ("Confederalists") over the "Centralists" in the SKJ. The purges of the "Ranković clique" were particularly meticulous in Serbia, especially in Kosovo, where the Commission for Assessment of Irregularities in the work of the UDBA, led by Ali Šukrija, President of the Executive Committee of the Province, was formed. In the first few months, 885 (71 anonymous) petitions were received against the SDB employees, 763 of which were filed by Albanian and Turkish nationals. ${ }^{61}$ By the beginning of 1967 , the same authorities received 1,300,

60 Numić states, as per later remarks by Vuk Krnjević literary critic, editor of cultural and entertainment programs RTB, who insisted that the film character Selim (was named after Numić, Copic's friend) in the TV series "Eight offensives" directed by Soja Jovanović, is renamed in Sejdo, which was in the end done, S. Numić, op. cit., 483. Tito called for the abolition of the accused with the following words: "a number of people are in prisons, but main culprits are out. This is certainly an anomaly, but it was influenced by political considerations. We discussed about it and we have decided that after the guilty verdict the whole thing is abandoned and proclaimed their abolition. But abolition must also include those who were only following orders. Lately we have been receiving more letters from people who are carriers of commemorative and war medals... It's ultimately not easily to separate, but we still need to bring to trial the perpetrators of the most severe crimes from the Kosmet province, and perhaps from other parts where stubbornness and cruelty are recorded." AJ, VSJ, 212, f. 18, top secret 13/66, Stenogram razgovora druga Tita sa sudijama Vrhovnog suda Jugoslavije.

61 From Drenica - 164, Đakovica - 114, Priština - 112, Prizren - 50, Peć - 40... In the Kosovo UDBA there were 58.3\% Serbs, $28.3 \%$ Montenegrins and $13.3 \%$ Albanians, though the percent of them on the higher levels were less obvious because the most prominent positions were taken by A. Šukrija, Dž. Nimani, Š. Razak, M. Nimani and others, Lobi, op. cit. 
and together with the municipalities as much as 2,500 petitions. Apart from the obsolete criminal charges (causing bodily harm, abuse, etc.), there were about 200 complaints for arbitrary deprivation of life and infliction of serious bodily harm and similar acts that do not expire. Out of these, 75 were murders and 45 beatings to death. In 1956, confiscation of weapons was the most common reason for charges for harassment and violence against citizens. During 1966-1967 majority of all petitions submitted by the Commission, were from the public prosecutors in Peć; 50 cases for murder and other ways of loss of life. ${ }^{62}$ The Executive Committee of the SKS issued a recommendation to Regional Assembly of Kosovo to review the abuse of the Service and punish the responsible. Thousands of petitions to provincial commission meant inconvenience for many intelligence operatives in Kosovo. They were fired from work or sent to early retirement, some were even persecuted, but almost none convicted. This can only be explained by political factors and the fact that the decision at the highest party level was not to "rock the boat" and show lenience towards the former Service employees (which is evident in the case of abolition of the accused for wiretapping).

In Kosovo, only few SDB employees were sent to prison. Vujo Vojvodić, Chief of Police in Peć, famous for apprehending saboteurs, intruders from Albania to Kosovo, was sentenced to 5 years in prison. Ibro Haskaj, an employee of the security service in Priština, was sentenced to several years in prison, although his innocence was established by investigative judge Novak Tajić. Jovo Bojat, longtime Chief of SUP in Đakovica and Kosovska Mitrovica, spent 6 months on remand in Peć due to the death of three illegals at the border. When his innocence was established, he was accused with an explanation that had he arrested them they would not have reached the boarder. Mirko Ilić, an employee of the SDB in Đakovica, was convicted of murder of the saboteur Ređa Derviš. Vlado Dašić and Mile Vujović, employees of the SDB in Peć, were in remand for more than 2 months for similar charges. Golub Dončić, UDBA operative, lost his job because he kept a picture of his grandfather with Karađorđe decoration on the chest in his apartment, and Mile Kostić, a police Chief in Peć, for selling his own hunting rifle. ${ }^{63}$ Although under investigation for serious murders (75), in spite heavy pressure on the judiciary and

62 AJ, VSJ, 212, f. 18, Kratka informacija o stanju krivičnih postupaka protiv pojedinih radnika UDB-e i milicije u vezi samovoljnih ubistava i maltretiranja građana Kosova, 20. januar 1967, 1-3. 
police, none of them were charged. This clearly shows the merits of the evidence against the suspects, which was acknowledged in the report of the federal public prosecutor: "The fact that no indictments were filed until now, public and relevant law instances find it alarming and view it as opportunism or excessive caution and unnecessary pedantry of the prosecution ... I believe that we should reject any attempt to sow doubt about the legality of work, qualifications and judicial benevolence of the administration." It is noticeable prudence of the competent authorities "they avoid hasty processing that could end in acquittals and thus create an awkward situation on the ground." ${ }^{4}$ Together with the Serbs fired from the UDBA, according to Vojin Lukić, were loyal Albanians as Šerif Bala, Head of the Secret Police in Peć and Hajri Đota, Head of Counter-intelligence Department of the UDBA for Kosmet. Staff ethnic cleansing of the top level UDBA Kosovo staff began. Many employees were evicted from Priština (mostly Serbs) under the pretext of reorganization of the UDBA and rationalization of jobs. Slavko Zečević said that over 80 operatives from Kosovo were given apartments in Belgrade and in this way the Albanian leaders got rid-off the Serbs and Montenegrins. The only one who refused to move to Belgrade was Radovan Grković. The main instigators of the reorganization the UDBA in Kosovo were Fadilj Hodža and Jovan Veselinov. ${ }^{65}$

In the campaign against centralism and Unitarianism, the wife of Aleksandar Ranković, Ladislava Savka Ranković, was removed from the position of professor of the Faculty of Economics in Belgrade. She was accused by the federal prosecutor that three special telephone lines were installed in her study in a family house wiretapping Tito's special line. ${ }^{66}$

Dobrica Ćosić was one of the few Communists who seriously opposed ousting of Ranković in a personal letter to Tito. In the fall of 1965, Tito allegedly indirectly offered Dobrica Ćosić to support him for the leader's position at the KP of Serbia, which could be interpreted from a later perspective, as an attempt to lobby the ousting of Ranković. ${ }^{67} \mathrm{On}$

64 AJ, VSJ, 212, f. 18, Kratka informacija o stanju krivičnih postupaka protiv pojedinih radnika UDB-e i milicije u vezi samovoljnih ubistava i maltretiranja građana Kosova, 20. januar 1967, 1-10.

65 S. Zečević, op. cit., 221.

66 Numić, op. cit., 526.

67 Tito allegedly held Dobrica Ćosić suitable the in-between between separatists Kardelj and centralists Ranković. Kirbus, „Moskovska zdravica za Rankovića“; Izjava novinara Svete Đukića, Crveno i Crno, TV-dokument, 11. 4. 2008; Slavoljub Đukuć, Političko groblje, (Beograd, 2009). 
May 29 $9^{\text {th }}, 1968$ at the XIV session of the Central Committee SKS, it was already decided that, respecting the decisions of the Brioni Plenum, Dobrica Ćosić and Jovan Marjanović were to be convicted for having raised their voices against the persecution and discrimination of the Serbian people in Kosovo which, according to them, intensified after the fall of Ranković. Many UDBA employees suspected as the "Ranković clique" were removed or retired from diplomacy, such as Živadin Žika Simić. ${ }^{68}$ On the other hand, on May $13^{\text {th }}$, honouring the $20^{\text {th }}$ anniversary of the security service, poet Oskar Davičo, has publicly supported the condemnations as "a decisive act of democratization of the party and society". ${ }^{69}$

\section{Persecution of Vojin Lukić and Boško Vidaković in 1973}

They were the only Ranković's supporters who were genuinely prosecuted and convicted for the classic verbal delict in the context of the intensification of repression against all internal enemies in the early 70s. They were arrested on March $2^{\text {nd }}, 1973$, at the time of the clash with the Maspok in Croatia and liberals in Serbia. Vojin Lukić (1919) born in Subotica, near Valjevo, holder of the highest partisan decorations and Commander of the $2^{\text {nd }}$ Proletarian Brigade, a former member of the Central Committee and the SKS, Republican (1953-1963) and Federal Police Minister (1963-1965) and Belgrade attorney Boško Vidaković, former officer in the Department of information and documentation DSIP and Federal Secretary for Foreign Affairs in retirement.

The process for "enemy propaganda" against Vidaković was initiated at the Belgrade District Court. He was accused for being heard on several occasions speaking "maliciously and falsely presenting the socio-political situation in the country and doing so he was working on breaking brotherhood and unity of the peoples of Yugoslavia." The incriminating incidents happened in the period from 1967 to 1972 in the restaurants Madera and Smederevska noć, Hotel Elan in Arilje and two private apartments. Among other things, he said, "The foreign policy of our country is pro-Western (...) after the Fourth plenum of the Central

68 Živadin Simić pre-war member of the KPJ and professional member of the King of Yugoslavia Army. After the war was ambassador in several countries and secretary of the Committee of SK in the Secretariat of Foreign Affairs. S. Zečević, op. cit., 159.

69 At the literary competitions for the anniversary of the Service in 1964, B. Mihajlović Mihiz participated with a heartfelt story about A. Ranković, D. Ćosić with a story about Josip Broz and P. Džadžić with an essay about SKJ. Mihiz was the unofficial winner. Duhaček, op. cit., 198. 
Committee, many good SSIP employees were fired" or "You, people from Smederevo and Požarevac, you are such Serbs, and if you fail Serbia, then you can go to hell. Who is going to defend the Serbian cause, if not us, we the citizens of Užice, you from Smederevo! You from Šumadija. Draža Marković and Moma Marković are scum (...) They are not Serbs, they are traitors (...) Our country is in a chaotic state (...) Many revolutionaries have been removed. Kardelj and Bakarić remained. Who will dare seize their personal planes and equity they have in foreign banks; (...) Liberals in Serbia are brought to power by Petar Stambolić, Bakarić and Kardelj (...) Tito has the power to bring to power individuals who suit him, but a difficult situation that was created in our country, cannot be repaired. The country lacks the concept of policy and theft rules." For such radical criticism of top leaders of Serbia and Yugoslavia, Vidaković received surprisingly lenient sentence of only one year and two months in prison. Vojin Lukić, who after the ousting practiced law, was also sentenced to a relatively light sentence of 18 months on probation, and under the same article, was charged for verbal abuse and similar alleged verbal statements. The accused were represented by a reputable attorney Veljko Kovačević. ${ }^{70}$

The persecution of the "Ranković cliques" went as far as to label views which aimed at strengthening of the Federation as "Ranković politics". Siniša Veličković, director of the Župa promet (Župa trade) from Aleksandrovac was arrested in 1974, and sentenced to four years for "techno-management machinations," accusing him of being of the "Ranković and Vojin Lukić cliques". ${ }^{71}$ During the 70 s in Croatia, in the campaign against the "Unitarian" Vicko Krstulović, who was opposing Bakarić, he was accused for having "close ties with Ranković and some members of the Praxis."72 The SDB reports during the 70s describe some of the "Ranković cliques" as being re-activated and meeting frequently. The reports also say that Ranković had established contact with the fugitive techno-manager Bata Todorović via a foreign suspicious intelligence agent

70 Rajko Danilović, Upotreba neprijatelja, (Valjevo, 1991), 105-106.

71 AJ, Predsedništvo SFRJ (SFRY Presidency), 803, 631-06/1975, Izveštaj o anonimnoj dostavi iz Kruševca.

72 Bakarić was accused by Vicko Krstulović at the V congress SKH. He was accused of favouritism of Dalmatia at the expense of Zagreb and improper attitude towards the role of critical intelligence. Zdenko Radelić, Hrvatska u Jugoslaviji 1945-1990, (Zagreb: Globus, 2006), 363. 
Sušić. ${ }^{73}$ Milan Trešnjić, a close associate of Vojin Lukić and longtime SSIP officer said: "Ranković was utterly faithful to Tito, honest and a good man, but naïve. I knew his wife Slavka, a great woman. He did not belong to the world from Dedinje, which Đilas describes in his books. Srba Savić and Vojin Lukić, great professionals and honest patriots were sacked just because they were Ranković's close allies. That was a game of the Slovenians and Croats. A way to make it easier to carry out a process of disintegration of Yugoslavia.... ${ }^{74}$ On the other hand, Dušan Čkrebić believed, that after the fall of Ranković, Serbia had an easy way in getting approved economic projects (Đerdap, Sartid, EI Niš....). ${ }^{75}$

The reasons for the dismissal and prosecution of Ranković and his supporters should be sought in the sphere of higher politics, although there were various personal motives of individual officials, some of which were touched upon. Primarily, he did not fit in with the "federalists" (Kardelj and Bakarić), since Ranković was persistent and consistent advocate for integrated Yugoslavia and a cautious approach of the national question and its provinces, for which he later enjoyed certain popularity in Serbia. Posthumously, he was even declared a "Serbian nationalist". Tito, according to these views, was mostly above these divisions and switched sides, tactically and according to his own estimates and visions. He often steered a middle course between these streams (such as in the field of foreign policy vacillated between East and the West). ${ }^{76}$ Ranković's fall was a victory for other fractions in the SKJ, joined "conservative and lib-

73 AJ, Predsedništvo SFRJ, 803, 24-1975, 26. sednica, Neka aktuelna pitanja bezbednosti - izlaganje saveznog sekretara za unutrašnje poslove Franje Herljevića 18. marta 1975.

74 Testimony by Milan Trešnjić, OZNA Major and former Gen. Consul in Stuttgart, Belgrade January $29^{\text {th }}, 2009$.

75 Čkrebić, op. cit., 309.

76 About the A. Ranković affaire and wiretapping scandal, see: Lukić, op. cit; Numić, op. cit:; Bojan Dimitrijević, „Odjek Brionskog plenuma na Službu unutrašnjih poslova 1966-1970“, Istorija 20. veka 2/2001, (Beograd, 2002), 75-89; Jovan Popović, Momčilo Zečević, Brionski plenum - IV sednica SKJ, stenografske beleške, (Beograd: Arhiv Jugoslavije, 1999); D. Marković, S. Kržavac, Zašto su smenjivani, (Beograd, 1985), M. Zečević, op. cit;; Borivoje Marjanović, Aleksandar Ranković Leka, (Beograd, 2002); Aleksandar Ranković, Dnevničke zabeleške, (Beograd: Jugoslovenska knjiga, 2007); Kovač, Dimitrijević, Popović, op. cit. 
eral federalists" who clashed at the beginning of the 70s over the issue of liberal reforms. Given that some, like Ivan Stevo Krajačić and General Gošnjak, were perceived as dogmatists and centralists, their siding with Tito can be explained by Tito's enormous and unlimited authority. ${ }^{77} \mathrm{~A}$ somewhat different version, but not contradictory, is the one of Vojin Lukić, who said that the main instigator of the clash was Kardelj, who wanted to remove Ranković, who was Tito's trusted support and who would later have an easier way with the ailing Tito. Kardelj fed Tito's fear of wiretapping, which was for long consciously or unconsciously encouraged by Jovanka. ${ }^{78}$ It is interesting that neither Selim Numić nor Vojin Lukić believed that Tito had a major role in the conflict, but blamed it on Kardelj and those leaders close to him, especially the infighting careerists' senior UDBA operatives, Branko Damjanović and Edi Brajnik who allegedly "masterminded the whole thing on Tito". ${ }^{79}$

The career ambitions of individuals and conformist who were in bondage to Tito's authority should also be taken into account (Petar Stambolić, Draža Marković, Krste Crvenkovski, Cvjetin Mijatović), as well as of those who were his intimate friends (Ivan Stevo Krajačić) and who had personal reasons to deal with Ranković (Jovan Veselinov). Boris Krajger, who had experience in the staging of the Dahau process in 1948, allegedly advocated even harsher measures against the accused members of the security services.

By the nature of their functions brothers Ivan and Milan Mišković, leaders of civil and military security services had a significant role. Later on, the Serbian public often emphasized the fact that in the political liquidation of Ranković most important roles were played by the Croats and Slovenians, which was perceived as a defeat of Serbian nationalism and among the Croats, Slovenes and Albanians it was celebrated as a victory. ${ }^{80}$ Surprisingly aggressive campaign against Ranković, as he calmly and wordlessly retreated to private life, testifies that the real goal was to create the political climate for change in the concept of Yugoslavia. Fierce campaign of administrative changes and decentralization of the Security

77 Radelić, op. cit., 364.

78 Lukić, op. cit., 109.

79 Branko Damjanović WW2 soldier, investigator and assistant manager of the Goli Otok prison. Then-Secretary of the SSUP, a longtime operative and head of the federal UDBA. He remained in the service after the Brioni Plenum in which he played a significant role in dealing with Ranković. Retired during the 80s. Numić, op. cit., 107; Lukić, op. cit., 110.

80 Radelić, op. cit., 362. 
Service were followed by a large-scale declarative democratization, decentralization and practically confederation of SFRJ. So, this event is often viewed and perceived by some participants and analysts only as the first in a series of events with the ultimate aim of liquidating the Yugoslav secret services as well as creation and introduction to the subsequent gradual confederation and the disintegration of the country. ${ }^{81}$

\section{Sources and Literature}

\section{Sources}

- Arhiv Jugoslavije:

- Centralni komitet Saveza komunista Jugoslavije, 507, IV/9.

- Kabinet predsednika Republike, 837.

- Predsedništvo SFRJ, 803.

- Savezno izvršno veće, 130.

- Vrhovni sud Jugoslavije, 212.

\section{Literature}

- Chrampton, Richard and Ben. Eastern Europe in the Twentieth century. London, 1997.

- Čkrebić, Dušan. Pogled iskosa. Beograd: Službeni glasnik, 2009.

- Danilović, Rajko. Upotreba neprijatelja. Valjevo, 1991.

- Dimitrijević, Bojan. „Odjek Brionskog plenuma na Službu unutrašnjih poslova 1966-1970“. Istorija 20. veka 2/2001, (Beograd, 2002).

- Duhaček, Antun. Ispovest obaveštajca. Beograd: Grafopress, 1992.

- Đukić, Slavoljub. Političko groblje. Beograd, 2009.

- Kirbus, Veljko. „Moskovska zdravica za Rankovića, Prisluškivači“, feljton. Revija 92, br. 684, 2. jun 2009.

- Ko je ko u Jugoslaviji. Beograd: Sedma sila, 1957.

- Kovač, Svetko, Bojan Dimitrijević i Irena Popović. Slučaj Ranković - iz arhive KOS-a. Zagreb: Infinitus, 2016.

- Krivokapić, Boro. „Samoubistvo šefa kabineta“, feljton Beskonačni Tito 5. Večernje novosti, 5. februar 2008.

- Lobi, Mark. Tajne službe Srbije. Beograd: Narodna knjiga, 2001.

- Lukić, Vojin. Sećanja i saznanja. Podgorica, 1989.

81 Duhaček, op. cit., 207. 
- Marjanović, Borivoje. Aleksandar Ranković Leka. Beograd: Knjiga komerc, 2002.

- Marković, Dragan i Sav. Kržavac. Zašto su smenjivani. Beograd: Narodna knjiga, 1985.

- Numić, Selim. Dobra zemljo lažu. Beograd: IRO Nova knjiga, 1989.

- Pavlović, Momčilo. Dokumenta CIA o Jugoslaviji 1948-1983. Beograd: Institut za savremenu istoriju, 2008.

- Piljak, Milan. „Brionski plenum 1966. godine: pokušaj istoriografskog tumačenja događaja“. Tokovi istorije 1/2010.

- Pirjevec, Jože. Jugoslavija 1918-1992. Kopar, 1995.

- Popović, Jovan i Momčilo Zečević. Brionski plenum - IV sednica SKJ, stenografske beleške. Beograd: Arhiv Jugoslavije, 1999.

- Radelić, Zdenko. Hrvatska u Jugoslaviji 1945-1990. Zagreb: Globus, 2006.

- Ranković, Aleksandar. Dnevničke zabeleške. Beograd: Jugoslovenska knjiga, 2007.

- Ridli, Džasper. Tito, biografija. Beograd: Mir, 1998.

- Simić, Pero. Raspeto Kosovo. Beograd: Novosti, 2006.

- Simić, Pero. Svetac i magle. Beograd: Službeni list, 2006.

- Tripalo, Mika. Hrvatsko proljeće. Zagreb: Globus, 1990.

- Zečević, Momčilo. Početak kraja SFRJ - Stenogram i drugi prateći dokumenti proširene sednice Izvršnog komiteta CK SKJ. Beograd, 1998.

- Zečević, Slavko. Sećanja i kazivanja. Beograd, 2004.

- Đokić, Velimir. Robijanje demokrate, književnika i akademika Pekića. Neobjavljen rukopis u posedu autora.

- Testimony by Jovo Kapičić. Crveno i crno, TV Document. 11 April 2008.

- Testimony by Milan Trešnjić, OZNA Major and former Gen. Consul in Stuttgart. Belgrade January 29, 2009.

- Trešnjić, Milan. Podaci za biografiju Josipa Broza Tita. Neobjavljen rukopis, u posedu autora. 


\title{
Резиме
}

Срђан Цветковић

\section{Пад Александра Ранковића 1966. и осуда „ранковићевштине“}

\begin{abstract}
Апстаркт: Рад се бави околностима под којима је смењен Александар Ранковић, дугогодишњи први човек државне безбедности, и утицајима које је ова смена имала на историју Југославије. Политички пад Александра Ранковића се поклопио са почетком редефинисања односа у федерацији и тиме код многих изазвао сумњу да су та два догађаја тесно повезана, а Ранковић је пак посмртно промовисан у српског националисту. Које су све афере везиване за његово име у време смене, колико има истине у оптужбама о прислушкивању југословенског руководства и његовим лидерским амбицијама и шта је то значило у контексту укупне државне политике такође су теме које се разматрају у овом чланку.

Кључне речи: Александар Ранковић, Управа државне безбедности, комунизам, Србија, политичке чистке, партијске чистке, Јосип Броз Тито
\end{abstract}

Разлоге за смену Ранковића и прогон његових присталица треба тражити у сфери високе политике, мада је било и различитих личних мотива код појединих функционера. Ранковић је као унитариста првенствено сметао федералистима у СКЈ (Кардељ, Бакарић) будући да се упорно и доследено залагао за интегралну Југославију и за обазривији однос према националном питању и покрајинама. Постхумно је чак због тога у Србији поглашаван за „српског нациналисту“, што не одговара истини. Тито се дуго држао изнад подела у партији и приклањао час једнима час другима, тактички и према властитим проценама и визијама, (као што је на плану спољне политике лавирао између Истока и Запада). На крају одлука је пала. Афера прислушкивања и остале оптужбе само су конструкција у процесу Ран- 
ковићеве политичке ликвидације. Изненађујуће агресивна кампања против њега, с обзиром на то да се он мирно и без речи повукао у приватни живот, као да сведочи о томе да је прави циљ било стварање политичке климе за промену концепције Југославије кроз декларативну демократизацију, а у ствари практично конфедерализацију СФРЈ. Стога се често овај догађај наводи и доживљава код појединих актера и аналитичара само као први у низу с крајњим циљем ликвидације тајне службе као југословенске творевине и увод у каснију поступну конфедерализацију и дезинтеграцију земље. 